УДК 351. 82:658

\author{
N. Datsii, \\ doctor of sciences in public administration, professor, professor of the department \\ of economic theory, intellectual property and public administration \\ Zbytomyr National Agroecological University \\ ORCID ID:0000-0003-0640-6426 \\ T. Ostapcbuk, \\ Master of specialty "Public Administration and Administration" of the department \\ of economic theory, intellectual property and public administration \\ Zbytomyr National Agroecological University \\ ORCID ID:0000-0002-3305-2144
}

DOI: $10.32702 / 2306-6814.2019 .12 .112$

\title{
INTEGRATION OF EDUCATION AND SCIENCE IN THE PROCESS OF REGULATION OF THE INTELLECTUAL CAPITAL DEVELOPMENT OF TERRITORY
}

\author{
Н. В. Аацій, \\ А. держ. упр., професор, професор кафедри економічної теорії, інтелектуальної власності та публічного \\ управління, Житомирський національний агроекологічний університет \\ Т. В. Остапчук, \\ магістр спеціальності "Публічне управління та адміністрування" кафедри економічної теорії, інтелектуальної \\ власності та публічного управління, Житомирський національний агроекологічний університет
}

\section{ІНТЕГРАЦІЯ ОСВІТИ І НАУКИ В ПРОЦЕСІ РЕГУ АЮВАННЯ РОЗВИТКУ ІНТЕ АЕКТУААЬНОГО КАПIТА $А$ ТЕРИТОРIї}

The article presents the principal structure of the goals, means and results of the functioning of a unified system of preparation of innovative personnel on the levels of education and the preconditions and social innovations in all subsystems and levels of education accumulated both in Ukraine and in the world.

At the scientific and educational level, the development of the approach to further institutional development of science and education is proposed - through the development and implementation of mechanisms for reproduction of intellectual capital of Ukraine's research and innovation personnel.

Conceptually, this mechanism is intended to harmonize the content, pedagogical technologies, curricula and programs, from the level of preschool education, the development of inclinations and abilities in the school period, the formation of creative abilities of young scientists in the student, the purposeful formation of scientists-innovators in graduate school and doctoral studies. The mechanism should ensure the achievement of a high level and advanced character of training, retraining and advanced training of specialists in promising areas of science and technology, improving the quality of education and the efficiency of scientific research.

Conducting technical modernization and advanced training create conditions for the transition to an innovative economy model. There is a whole range of proposals that would significantly increase the number of private-public or public-private projects; partnership. Including Infrastructure.

The sequence of a higher role for business in the management of private-public partnership institutes, including such as project expertise, the creation of registers of both implemented projects and projects that are envisaged to implement such a partnership. That is, it is not just a partnership in the development of budget money, but also a partnership in the creation of development institutes, public-private partnership institutes. 
The sequence of state actions in the development, coordination and implementation of this system is defined: 1) the formulation of national goals related to the development of the scientific and educational complex; 2) the formation of the scientific and educational system of society; 3) creation of favorable conditions for the agreed programs of modernization of its subsystems and further development; 4) clarification of the regulatory framework; 5) clarification of the state budget policy in the field of financing science and education; 6) the formation of favorable conditions for involvement in the business system.

У статті представлено принципову структуру цілей, засобів і результатів функціонування єдиної системи підготовки інноваційних кадрів за рівнями освіти та передумови і соціальні інновації по всіх підсистемах і рівнів освіти накопичені і в Україні, і в світі.

На науково-освітньому рівні запропоновано розроблення підходудо подальшого інституційного розвитку науки і освіти - через розробку та впровадження механізмів відтворення інтелектуального капіталу науково-інноваційних кадрів України.

Концептуально такий механізм покликаний погодити зміст, педагогічні технології, навчальні плани і програми, починаючи з рівня дошкільної освіти, розвитку схильностей і здібностей в шкільний період, формування творчих здібностей молодих вчених устудентстві, цілеспрямованого формування учених-інноваторів в аспірантурі та докторантурі. Механізм має забезпечити досягнення високого рівня і випереджаючий характер підготовки, перепідготовки та підвищення кваліфікації фахівців по перспективних напрямках науки і технологій, поліпшення якості освіти та ефективності наукових досліджень.

Проаналізовано, що проведення технічної модернізації та підвищення кваліфікації створюють умови для переходу до інноваційної моделі економіки. $€$ цілий комплекс пропозицій, які дозволили б істотно збільшити кількість проектів приватно-державного, або державно-приватного; партнерства. В томучислі і інфраструктурних.

Доведено, що більш висока роль бізнесу в управлінні інститутами приватно-державного партнерства, в тому числі таких, як експертиза проектів, створення реєстрів як реалізованих проектів, так і проектів, що намічаються до реалізації такого партнерства. Тобто мова йде не тільки партнерство в освоєнні бюджетних грошей, але й про партнерство у створенні інститутів розвитку, інститутів державно-приватного партнерства.

Визначено послідовність дій держави з розробки, узгодженню та здійсненнютакої системи: 1) формулювання національних цілей, пов'язаних з розвитком науково-освітнього комплексу; 2) формування науково-освітньої системи суспільства; 3) створення сприятливих умов для узгоджених програм модернізації ії підсистем і подальшого розвитку; 4) уточнення нормативноправової бази; 5) уточнення бюджетної політики держави у сфері фінансування науки і освіти; 6) формування вигідних умов для залучення в систему бізнесу.

Key words: innovation of personnel, integration of education, intellectual capital, mechanisms, modernization of science, territory.

Ключові слова: інновація кадрів, інтеграція осВіти, інтелектуальний капітал, механізми, модернізація науки, території.

The purpose of the article is to determine the mechanism of formation, accumulation and reproduction of intellectual capital of Ukraine's research and innovation personnel; substantiation of mechanisms of integration of education and science in the process of regulating the development of intellectual capital of the territory.

\section{FORMULATION OF THE PROBLEM}

The main condition for the transition of Ukraine to the "knowledge economy" is the formation of a modern national innovation system. Ukraine is at the start of largescale modernization. The structure of the economy is expected to change from raw material to innovation. Intellectual capital can only be developed by innovative personnel. Therefore, Ukrainian business and foreign partners worry about the lack of skilled personnel in Ukraine. Competence and activity of innovative personnel depends, first of all, on the accumulated intellectual capital. The development of the national education system becomes a key element of global competition and one of the most important vital values. And Ukraine has everything: both rich traditions and the potential to make Ukrainian education - from school to university - one of the best in the world.

The field of education is the basis for the expansion of scientific activity. In turn, science also has a significant educational potential. It is necessary to promote talented young scientists who carry out active research, help them successfully integrate into scientific and innovative environments. Investments in research and development 
from business should be stimulated by the state and grow. Incremental and directed state resources should be used as efficiently as possible and focus on fundamental and breakthrough trends. In order to assess the opportunities and prospects for the integration of science, education and business, it is necessary to take into account a number of peculiarities of the domestic scientific and educational complex and the changes taking place in it, the core of which are independent specialized research organizations.

\section{ANALYSIS OF RECENT RESEARCH AND PUBLICATIONS}

The following foreign scientists contributed to the theory of intellectual capital: R. Kaplan, D. Norton, and others. Methodological aspects of the assessment of intellectual capital are highlighted in the writings of such scholars as O. Veretennikova, V. Inozemtsev, S. Ilyashenko, N. Krikun, M. Melon, E. Seleznev. The mechanism of intellectual capital management is devoted to the work of M. etrushenko, F. Mamatov. The question of formation and reproduction of intellectual capital is reflected in the scientific works of K.V. Kovtunenko.

\section{PRESENTING MAIN MATERIAL}

Prospects for building an intellectual-innovative system in Ukraine, especially at the territorial level, are hampered by existing institutional conditions. The ability of the national economy to innovate, as well as the ability to introduce advanced foreign technology, is reduced.

The strategic course of development of the state policy of Ukraine is oriented towards the formation of its innovative model, but economic and financial problems hinder this process and do not allow the country to achieve the proper level of innovation development.

The situation in the field of education is characterized by such problems [6, p. 28]:

- Inadequacy of the quality of education to modern requirements. Ukraine is not represented in any of the major international rankings of the best universities. About $20 \%$ of employers point out the inconsistency of the qualifications of employees in their position. Ukraine closes the first hundred countries for use in the educational process of information and communication technologies;

- inefficiency of the mechanism of state financing of the education system. The level of provision of comprehensive schools with modern means of study (cabinets of biology, physics, chemistry) is $29.3 \%$ of the need. The main items of budget expenditures are not aimed at improving the quality of education, but on salary payments and utility payments (over $70 \%$ of total funding);

- an increase in disproportions between the training of specialists and the demand for them in the labor market. In the formation of plans for the recruitment of students, institution of higher education proceeds from the reasons of maintaining the contingent of students and teachers;

- lack of a single educational space.

In addition, the situation in Ukraine in the field of reproduction and change in the age structure of scientific and scientific and pedagogical personnel shows that the complex of state measures on attracting and securing the personnel that is being implemented is insufficient and does not make a decisive influence on the positive change in the situation. The key is the lack of a single program that supports the scientific research of young scientists in the period of their choice of life path, first of all immediately after the defense of the dissertation. The most important element is the attractiveness of a young researcher career. It is necessary to support the scientists and scientific and pedagogical teams that perform a dual role - firstly, they demonstrate the success of the profession of a scientist and teacher, and secondly, they carry out effective training of young scientific and scientific and pedagogical staff [4].

For the development of state regulation of the intellectual capital of a nation, it is necessary to clearly prescribe the forms of integration of science and education in the context of the broader task of integrating science, education and production. It is necessary to emphasize the need to include these processes in business in order to provide innovative development of the economy, but at the same time the integration of science and education is allocated to an independent task. So, it turns out that Ukraine should first integrate science and education and then merge business into it. Such a scenario is deliberately ineffective, especially since the world's leading economies have realized it in the second half of the 20 th century.

The practice of the leading industrialized countries shows an increase in the contribution of universities to the development of innovation and economic growth. Public funding for research in higher educational institutions is increasingly oriented towards specific socioeconomic goals and is dependent on the final results; the role of contractual financing is growing. Although higher education institutions in developed countries continue to perform the bulk of basic research (up to $50 \%$ of the total research and development in this sector), in a number of countries, the share of university research funding by industry is increasing from 8 to $14 \%$ (Canada, Belgium, Hungary, Germany, Turkey). In China, it reaches $37 \%$. Innovative orientation of the activities of universities is also ensured by the training of qualified scientists and engineers, the increasing participation of teachers and postgraduates in the execution of research and development, the transfer of their results to industry [3].

Ukraine recognized expediency and entered the Bologna process. However, the systematization of its tasks at all levels of education in this system is not yet available to the participating countries.

Taking into account the world experience and institutional features of the national scientific and educational complex in this area, the political will of the country's leadership is needed, not only to change budget priorities and improve its budget financing, but also to pursue a fairly rigid policy on the reform of Ukraine's scientific and educational complex.

Overcoming these shortcomings of the adopted program requires an approach to further institutional development of science and education - through the development and implementation of mechanisms for reproduction of intellectual capital of Ukraine's research and innovation personnel.

Conceptually, this mechanism is intended to harmonize the content, pedagogical technologies, curricula and programs, from the level of preschool education, the 
development of inclinations and abilities in the school period, the formation of creative abilities of young scientists in the student, the purposeful formation of scientists-innovators in graduate school and doctoral studies.

The mechanism is intended to ensure the achievement of a high level and advanced character of training, retraining and advanced training of specialists in promising areas of science and technology, improving the quality of education and the efficiency of scientific research. The sequence of government actions to develop, coordinate and implement this system includes the following measures:

1) the formulation of national goals related to the development of scientific and educational complex;

2) the formation of the scientific and educational system of society;

3) creation of favorable conditions for the agreed programs of modernization of its subsystems and further development;

4) clarification of the regulatory framework;

5) clarification of the state budget policy in the field of financing science and education;

6 ) the formation of favorable conditions for involvement in the business system.

This complicated and multidisciplinary program can only be developed with a systematic approach, with a clear link between the interaction of all levels of education, with a clear presentation that needs to be obtained at the outputs of each subsystem and level of education.

The Ukrainian school development program should include the following main areas.

The first is the creation of such learning environments in which children could already disclose their opportunities at school, prepare themselves for life in a high-tech competitive world.

Secondly, simultaneously with the introduction of new standards of general education, an extensive system of search and support for talented children, as well as their support throughout the period of personality development, should be built.

The third is the preservation, qualitative improvement and replenishment of the personnel of the teachers.

Fourth, the form of schools should change - both in form and in content.

The organizational structure of the educationalresearch-and-production complex is intended to provide an improvement in the quality of the implementation of a continuous, multilevel and multilevel form of vocational education with a significant reduction in overall costs by eliminating duplication, harmonization and curriculum, sharing and combining educational, laboratory, scientific, production space, educational, scientific, industrial equipment, computer technology, information funds, material and financial resources.

Implementation of this model of state regulation of intellectual capital requires revision of the entire university management system, the solution of a sufficient number of legal issues, the organization of financial flows and economic levers of influence on structural units, the development of various provisions, documentation for accounting and financial control.
In this model, the institution of higher education as a learning and research complex of the process of creating new knowledge in fundamental research, the implementation of new ideas in applied research is inextricably linked with the learning process: lectures, practical classes, coursework, graduation design, research and development, design work of students, dissertation work of postgraduate students and doctoral students.

The student is closely connected and works near a graduate student, a doctoral student, a professor, a producer. The higher level of the system is the individual training of scientists in postgraduate and doctoral studies. For postgraduate education in the XXI century, new qualitative characteristics are becoming dominant, which are manifested in each level of the innovation system.

The new mechanism for the development of intellectual capital can be educational, scientific and production complexes. In their structure, besides educational institutions, branches, colleges, faculties, scientific and educational-production divisions, various legal bases may include industrial enterprises with corresponding technological and design bureaus, experimental and experienced production, research and production centers and laboratories.

The organizational structure of the educationalresearch-and-production complex is intended to provide an improvement in the quality of the implementation of a continuous, multi-level and multilevel form of vocational education, with a significant reduction of overall costs by eliminating duplication, harmonizing curricula, sharing and combining educational, laboratory, scientific, production space, educational, scientific, production equipment, computer technology, information funds, material and financial resources.

The implementation of this mechanism requires revision of the entire university management system, the solution of a sufficient number of legal issues, the organization of financial flows and economic levers of influence on structural units, the development of various provisions, documentation for accounting and financial control.

Let's note the peculiarities of functioning of the subsystem of scientific work of postgraduate students and doctoral students at universities.

1. Personality orientation of dissertation tasks. The personal approach to education and science involves the individualization of scientific tasks, the formation of not only professional abilities, but also personal qualities that allow you to work comfortably and live in a modern, democratic society. High professionalism and active social position in society should distinguish the scientist, including candidate and doctor of sciences, intended to enter the intellectual-social elite of society.

2. A personal approach to the implementation of the Scientific research work requires an individual planning of activities, both in terms of research work and the timing of its implementation. The most important part of the activity of scientists is their mastery of methodology and methods of scientific research, which allows you to move from the principle of "scientific degree to life" to the principle of "scientific search through life". Continuous and fairly fast updating of knowledge requires a corresponding 
personal mood, readiness and skills of continuous selfeducation throughout the active scientific life. Subsystem of organization of scientific work, including postgraduate education in the course of modernization should be able to provide beginners and current scholars with the necessary set of educational services continuous in all stages of the life cycle of innovation.

3. Fundamentalization of science and education. Fundamentality of the preparation and work of the scientist in certain respects confines narrow specialization of scientific research. Since the hard work gained in the knowledge of outdated or changing, then the ability of scientists should have an invariant basis, a methodological foundation that allows timely adaptation of knowledge to new living conditions. Truth is always relative, and the search for "eternal motor" is only a motive for the constant improvement of knowledge.

4. Freedom of choice. Excessive regulation of the creative process, as a rule, is less productive, compared with the conscious freedom of choice. The scientist achieves the best results in a conscious self-organization of the creative process. Choice of scientific organization and scientific school, individual work plan, collection and selection of information and methods of analysis, opportunities for contacts with the manager and consultants, availability of communication channels, forming personal goals in scientific activity. Free expression forms an irreplaceable creative environment, directing the search in a productive direction.

5. Development of scientific and information culture. In the modern information society, those researchers who have mastered the skills of scientific research and a sufficient level of information culture are seeking success. The scientific and informational culture of the scientist represents a stable system of knowledge and skills of selection, analysis and synthesis of scientific information in the general information space. The intellectual potential of the researcher, the time and performance of his work largely depend on the level of his personal scientific and information culture [1].

6 . Free access to world information resources. Already hundreds of millions of people have access to the Internet. Scientists, graduate students and doctoral students should have free access and sufficient time to enter their network and database. Directories, encyclopedias, scientific journals, virtual scientific conferences, sites of scholarly schools and individual scholars become available and accelerate the weight of the phase of scientific work.

An effective mechanism of state regulation of the development of scientific and educational activities at universities should be based on the observance of the agreed principles by all participants in the creative process. In our opinion, these principles should include the following provisions:

- early detection, consolidation and development of creative abilities of students with their orientation to scientific work;

- Individual planning of the activities of scientists and applicants, taking into account the field of science, personal abilities, the availability of information resources;

- freedom of choice of place, time and rate of research;
- the transition from the principle of "scientific degree to life" to the principle of "science through life";

- reliance on worldview, semantic models of knowledge of the world on the synergistic level of integrity and interconnection of man, society and nature;

- free development of individuality, creative potential and opportunities for its implementation.

The main tendencies of state regulation of the effective development of intellectual capital in the field of higher education can be considered as follows [5]:

- improvement of the quality of training of scientists on the basis of fundamentalization, the widespread use of new methods of scientific research, the use of modern information technology;

- the leading nature of scientific works, including dissertation researches, their focus on solving perspective problems in reproduction of innovations with life cycle up to $10-15$ years;

- increasing the availability of scientific and postgraduate education, especially for small towns and rural areas through the use of information and telecommunication technologies;

- development of creative abilities (creativity) in the preparation of scientists and teachers with the formation of personal qualities necessary for successful activities in different conditions. Systemic scientific thinking, creative activity, scientific and information culture, high morality provides sufficient adaptability of specialists, their creative role in the development of society and civilization.

In order for a new knowledge to be generated and implemented in the country, an appropriate infrastructure is needed. Ukraine has always been rich in inventions, but there has never been a clearly established mechanism for commercializing inventions. Fragmentary solutions do not create them. Necessary system that covers all sectors, all aspects of life. For this purpose, it is necessary to increase the support of fundamental science, while improving the organization of this science. And the task is to ensure that the support infrastructure for such activities is not local. This system should be comprehensive, from pre-school education and education to postgraduate vocational education and business communication. The united system of training of innovative-oriented personnel envisages expansion and legal regulation of institutes, infrastructure, provides innovative reproduction of intellectual capital and attraction of necessary investments [2; 7].

1. New organizational forms: schools at leading universities of the country. In Ukraine, it is necessary to expand and coordinate the work of state and territorial networks of innovative schools in the branches of science - physics, chemistry, mathematics, biology, economics, history, etc.

2. Further development of the network of territorial educational production-innovation complexes, which includes manufacturing enterprises, a multi-level education system: schools for talented children, colleges, and universities with clear territorial coordination are needed.

3. There is an objective need to develop a unified system for attestation of intellectual potential of personnel: the school - the final - postgraduate study doctoral studies - innovative activity. 
4. It requires harmonization of the process of investments into intellectual capital on the new principles of formation of training of innovative personnel, including:

- Accounting for the duration of the investment cycle for the training of scientific and innovative personnel in $20-30$ years;

- accounting of the real, not understated investment capacity of the educational process in preschool, school, university and postgraduate education;

- compulsory co-financing of training of personnel from the state, family, business with the definition of mutual social and economic effects;

- determination of the optimal proportions of cofinancing from pre-school, school, university and postgraduate vocational education.

\section{CONCLUSIONS}

Many things have already been done in Ukraine. Infrastructure is created, investment funds work, industrial parks work, special economic zones have appeared. Breakthrough programs for the development of nanotechnologies, biotechnologies, information and communication technologies of energy, industrial infrastructure, aircraft building and shipbuilding, etc. are determined. The main unresolved issue is the commercialization of the results of scientific research. This task should be solved by business with its entrepreneurial culture, the willingness to invest in risky projects and thus return the economy to an innovative way of development.

In order the idea to be perceived by business, the idea must become a product. And here the irreplaceable role of education. At present, many achievements are based on the successes of the old Soviet school. It has traditions that have helped to succeed in current activities, but there is no major - effective approaches to what should be a modern professional researcher, scientist, manager.

Competition for knowledge and, consequently, the continuity of education allows a student, entrepreneur or researcher to develop throughout his professional life. It is about creating a national system for assessing intelligence and qualifications, in which qualifications are confirmed and awarded, as well as recognized learning outcomes regardless of whether they are obtained in a permanent institution of vocational education, at the enterprise or on their own.

Conducting technical modernization and advanced training create conditions for the transition to an innovative economy model. The infrastructure is of ten not a foundation but a barrier to development. There is a whole range of proposals that would significantly increase the number of private-public or public-private projects; partnership. Including Infrastructure.

A higher role for business in the management of private-public partnership institutes, including such as project expertise, the creation of registers of both implemented projects and projects that are envisaged to implement such a partnership. That is, it is not just a partnership in the development of budget money, but also a partnership in the creation of development institutes, public-private partnership institutes.

The proposed unified system of state regulation of intellectual capital will allow uniting all levels of education into a single, uninterrupted system of formation and development of intellectual capital of the territory.

\section{References:}

1. Zharinova A.G. (2014), "Theoretical and economic approaches to the definition of the phenomenon of intellectual capital", Aktual'ni problemy ekonomiky, vol.1, pp. $5-16$.

2. Kovtunenko K.V. (2013), "Main Approaches to the Formation of Intellectual Capital: Content and Role in Innovative Development of an Enterprise", Ekonomika rozvytku, vol. 3, pp. 59-62.

3. Mamatov, F.M. Usakov, Z. U. (2015), "Integration of Education, Science and Production as a Factor in the Development of an Innovative Economy", Onovlennya zmistu, form ta metodiv navchannya i vykhovannya $v$ zakladakh osvity, vol. 7, pp. 98-101.

4. Petrushenko, M.M. (2012), Motyvatsiyni chynnyky upravlinnya znannyamy pry formuvanni intelektual'noho kapitalu [Motivational factors of knowledge management in the formation of intellectual capital], Socio-economic motivation of innovation development of the region: monograph. Sums'kyy derzhavnyy universytet, Sumy, Ukraine.

5. Degtyar, A.O. Amosov, O.Yu. Batinin, M.A. (2018), Realizatsiya polityky innovatsiyno-investytsiynoho rozvytku ekonomiky na rehional'nomu rivni [Realization of the policy of innovation and investment development of the economy at the regional level], Vyd-vo KharRI NADU "Mahistr", Kharkiv, Ukraine.

6. Sychenko, V.V. (2017), "Realization of the Integration Policy of the State in the Field of Higher Education", Aktual'ni problemy derzhavnoho upravlinnya, vol.1 (35), pp. 24-35.

7. Solovyov, V.P. Korienyako, G.I. Holovatyuk, V.M. (2010), Innovatsiynyy rozvytok rehioniv: pytannya teoriyi i praktyky [Innovative development of the regions: questions of theory and practice], Feniks, Kyiv, Ukraine. Cтаття надійшла до редакиї̈ 04.06.2019p.

\section{www. dy.nayka.com.ua}

Електронне фахове видання

\section{ДЕРЖАВНЕЕМУРАВЛПННЯ удосконалення та розвиток}

\section{Виходить 12 разів на рік}

$$
\begin{aligned}
& \text { Видання включено до переліку } \\
& \text { наукових фахових видань України } \\
& \text { з ДЕРЖАВного уПРАвлІння } \\
& \text { e-mail: economy_2008@ukr.net } \\
& \text { тел.: (044) 223-26-28 } \\
& \text { (044) 458-10-73 }
\end{aligned}
$$

